STUDIA EDUKACYJNE NR 50/2018

\author{
Magdalena Andrys \\ Uniwersytet im. Adama Mickiewicza \\ w Poznaniu
}

\title{
FOLKLOR W EDUKACJI MUZYCZNEJ - METODA PROJEKTÓW
}

\begin{abstract}
Andrys Magdalena, Folklor w edukacji muzycznej - metoda projektów [Folklore in Music Education - a Project Method]. Studia Edukacyjne nr 50, 2018, Poznań 2018, pp. 399-411. Adam Mickiewicz University Press. ISSN 1233-6688. DOI: 10.14746/se.2018.50.26

In times of prevailing mass pop-culture there is almost no space for traditions and customs connected with folklore. Educationalists and music teachers continue to pursue progressive methods demonstrating the artistic values of folklore. Project-based learning is a method which can be the beginning of forming an attitude of respect and cultivation of national heritage. This method may not only can develop social abilities, teach self-reliance and organization, but also create an opportunity to find interest even among most difficult problematic issues. A recent project 'Muzyczna Kawaleriada z Uśmiechem - Regiony kulturowe Polski' has already created a possibility for researching if the above method can be applied for musical education for grades 4-6. Folk culture, especially songs and dances, has become a subject of observation for teachers and at the same time an evaluation for students. A questionnaire was used for that purpose. All three stages of the project, preparation, realization and presentation as well as the results of conducted research show that project-based learning is an attractive and effective method of music education. Certain values of the beauty of Polish folk songs and dances are also indicated.
\end{abstract}

Key words: folklore, music education, project method

Projekty edukacyjne stosowane coraz częściej w polskich szkołach są również tematem rozważań naukowych współczesnych dydaktyków. Innowacyjny i badawczy charakter może być atrakcyjny dla uczniów, stanowiąc jednocześnie wyzwanie również dla nauczycieli. Na jej korzyść przemawia kształtowanie umiejętności społecznych, nauka samodzielności, rozwój umiejętności organizacyjnych, indywidualnych zainteresowań i pasji.

Kierując się powszechnymi wśród pedagogów pozytywnymi opiniami, powstała idea sprawdzenia jej zastosowania w odniesieniu do edukacji muzycznej. Uwzględniając zmiany oświatowe w procesie kształcenia ogólnego, 
dostrzeżono potrzebę twórczej realizacji podstawy programowej obejmującej zagadnienia przedmiotu - muzyka. Placówką, która podjęła się takiej próby była Szkoła Podstawowa im. Kawalerów Orderu Uśmiechu w Kobylnicy, która udostępniła przestrzeń dydaktyczną dla projektu „Muzyczna Kawaleriada z Uśmiechem - Regiony kulturowe Polski". Tematyką przedsięwzięcia stała się szeroko pojęta kultura ludowa, w wyjątkowy sposób pielęgnowana w Roku Oskara Kolberga, przypadającym na okres przygotowań projektu. $Z$ tej przyczyny najważniejszym elementem efektu finalnego była istota folkloru ludowego - prezentacja śpiewu i tańca.

\section{Metoda projektów}

Metoda ta zaliczana jest do otwartych form uczenia się. Zalecenie jej stosowania $w$ edukacji doprowadziło do szerokiego zainteresowania nie tylko historią powstania, poszczególnymi etapami wdrażania, ale również wpływem na rozwój dziecka. Autorzy wielu publikacji poddając głębokiej analizie wszystkie jej aspekty, wyeksponowali najistotniejsze cechy wyróżniające metodę projektów na tle innych metod, a są nimi: progresywistyczna rola nauczyciela, podmiotowość ucznia, całościowość oraz odejście od (tradycyjnego) oceniania uczniów ${ }^{1}$.

W szkolnictwie metoda projektów stosowana jest od ponad stu lat. Może to oznaczać, że doskonale wpisuje się w realizację postulatów edukacyjnych. Za jej realizacją przemawiają korzyści wypływające z aktywnej działalności uczniów. Sięgając do literatury, można zaobserwować plastyczność jej wdrażania oraz opis poszczególnych etapów realizacji². Karl Frey, pedagog zajmujący się teorią metody projektów, wyodrębnił pięć faz przeprowadzania projektu: zainicjowanie projektu, rozważanie inicjatywy projektu z uwzględnieniem możliwości ich realizacji i wybór jednej z nich, opracowanie szczegółowego planu działania, wykonywanie projektu, ukończenie projektu ${ }^{3}$. Siedem etapów wdrażania metody proponują Bożena Potocka oraz Lesława Nowak: wybór zagadnienia - wyłonienie tematu, określenie celów projektu, zawarcie kontraktu, opracowanie programu projektu i harmonogramu działań, realizacja projektu, prezentacja projektu, ocena projektu4. Podział na cztery fazy postulują Agnieszka Mikina i Bożena Zając, uwzględniając jedno-

${ }^{1}$ M.S. Szymański, Rozprawa o metodzie (projektów), [w:] Pedagogika w pokoju nauczycielskim, red. K. Kruszewski, Warszawa 2000, s. 278

2 B.D. Gołębniak, Uczenie metodą projektów, Warszawa 2002, s. 54.

${ }^{3}$ M. S. Szymański, Wokót metody projektów Karla Freya, Kwartalnik Pedagogiczny, 1993, 3/4, s. 8 .

${ }^{4}$ B. Potocka, L. Nowak, Projekty edukacyjne, Kielce 2002, s. 7. 
cześnie szczegółowe czynności należące do nauczyciela i uczniów. Sugerowane fazy, to: przygotowanie projektu, wykonanie projektu, prezentacja i ocena projektu ${ }^{5}$. Autorki podkreślają, że metoda projektów stwarza możliwość dużej dowolności w wyborze sposobów działań, zarówno ze strony nauczyciela, jak i ze strony uczniów ${ }^{6}$. Wspomniane klasyfikacje etapów pracy metodą projektów pomimo różnic (liczba etapów, terminologii) zachowują sekwencję proponowaną przez W.H. Kilpatricka ${ }^{7}$, która stanowi trzon propagowany przez nowoczesną dydaktykę.

Obecna rzeczywistość daje mnóstwo możliwości dotarcia do wiedzy oraz kształtowania umiejętności. Powszechność i dostępność informacji staje się wyzwaniem w kwestii ich umiejętnego gromadzenia i wykorzystania. Współczesny młody człowiek nie tylko musi być wyposażony w wiedzę i kompetencje jej zdobywania, ale przede wszystkim powinien mieć dyspozycje intelektualne, które dadzą mu możliwość funkcjonowania w zmiennej rzeczywistości. Nauczyciele posiadający tę świadomość twórczo i z pełnym zaangażowaniem poszukują sposobów uskuteczniania własnych działań, niekiedy wychodząc poza schematy. Metoda projektów stwarza takie możliwości, wspierając rozwój dydaktyczny i wychowawczy. Oprócz widocznych efektów końcowych każdego projektu, istotne jest to, czego realnie dostrzec nie sposób. Uczniowie rozwijają pewność siebie, stają się samodzielni, rozbudzają w sobie entuzjazm, a także zauważają potrzebę podejmowania inicjatyw społecznych $^{8}$. Pracując w grupie, mogą stać się efektywnymi współpracownikami i liderami rozwijającymi w sobie umiejętności słuchania, zadawania pytań oraz dążenie do kompromisu przy osiągnięciu wspólnego celu, a dzieląc się własnymi ideami, rozwijają w sobie głębsze rozumienie wiedzy ${ }^{9}$.

\section{Edukacja muzyczna}

Muzyka towarzyszy człowiekowi od zarania dziejów. Niezależnie od formy, zawsze istniała $\mathrm{w}$ życiu codziennym społeczeństw. Pełniła wiele istotnych funkcji, choć najczęściej związana była z obrzędami i kultem religijnym. W historii każdego społeczeństwa element edukacji muzycznej stał się niezwykle ważny, bez względu na status danej grupy społecznej. Jej określona

\footnotetext{
${ }^{5}$ A. Mikina, B. Zając, Jak wdrażać metodę projektów? Poradnik dla nauczycieli i uczniów gimnazjum, liceum i szkoty zawodowej, Kraków 2004, s. 57-112.

${ }^{6}$ A. Mikina, B. Zając, Metoda projektów w gimnazjum, Warszawa 2002, s. 10.

7 W.H. Kilpatrick, The Project Method, Teachers College Record, 1918, XIX, 4.

8 S. Dylak, G. Barabasz, D. Hejwosz-Gromkowska, Metoda projektów w edukacji ponadpodstawowej, Poznań 2014, s. 114.

9 J.S. Krajcik, P.C. Blumenfeld, Project - based learning, [w:] Cambridge handbook of learning sciences, red. K. Sawyer, Cambridge 2006, s. 317-334.
} 
specyfika estetyczna przyczyniała się do zachowania tożsamości narodowej, natomiast w odniesieniu do jednostki dostrzeżono właściwości wspomagające rozwój osobowości. W kontekście kształtowania kultury muzycznej, pojawiła się konieczność edukacji muzycznej całego społeczeństwa, na każdym etapie rozwoju człowieka. Uwzględniając dwa zasadnicze cele - zachowanie historycznego muzycznego dorobku ludzkości oraz ogólnorozwojowy charakter - władze każdego państwa, tworząc system oświaty, włączają w proces edukacji również zajęcia muzyczne.

W polskich szkołach, w całym cyklu edukacyjnym, najwięcej godzin edukacji muzycznej (prowadzonej przez nauczyciela specjalistę) przypada na II etap edukacyjny (95 godzin). Można określić, iż w klasach IV-VI kształtowane są postawy ucznia wobec muzyki oraz jego przyszłego uczestnictwa w kulturze. Dlatego wówczas należy otoczyć szczególną troską dbałość o odpowiednią ilość pozytywnych doświadczeń muzycznych, które mogą przyczynić się do rozbudzenia potrzeby obcowania z muzyką. Sposobem na zainicjowanie uczniowskich poszukiwań muzycznych może być metoda projektów.

Nauczyciele wykorzystujący metodę projektów wskazują na rozwijającą aktywność, samodzielność, przedsiębiorczość i kreatywność uczniów, którzy poprzez dokonywanie wyborów, podejmują decyzje w celu znalezienia odpowiedzi na zadane pytania. Poprzez zabawę mogą poczuć się jak badacze i odkrywcy, odnajdując w ten sposób radość w nauce.

\section{Metoda projektu w edukacji muzycznej}

Napięte programy nauczania oraz znikoma liczba godzin przeznaczonych na lekcje muzyki w całym cyklu edukacyjnym skłaniają do podjęcia dodatkowych inicjatyw związanych z edukacją muzyczną. Pozytywne opinie na temat metody projektów oraz jej innowacyjny i interdyscyplinarny charakter stanowiły ważne argumenty podczas wyboru sposobu realizacji projektu "Muzyczna Kawaleriada z Uśmiechem ${ }^{10}$ - Regiony kulturowe Polski".

Rok 2014 został ogłoszony przez Sejm Rzeczypospolitej Rokiem Oskara Kolberga, dziewiętnastowiecznego folklorysty, etnografa oraz kompozytora, jednego z największych kronikarzy i popularyzatorów kultury ludowej, który całe swoje życie poświęcił opisywaniu zwyczajów wsi polskiej oraz spisywaniu pieśni i melodii ludowych ${ }^{11}$. Kolbergowska teoria nawołująca do

10 „Muzyczna Kawaleriada z Uśmiechem” - nazwa własna projektu, powiązana z imieniem patronów szkoły, w której projekt przebiegał - Szkoła Podstawowa im. Kawalerów Orderu Uśmiechu w Kobylnicy.

11 http://www.kolberg2014.org.pl/pl/2014/idea [dostęp: 30.03.2017]. 
dbałości o zachowanie tradycji i potrzeba edukacji regionalnej stały się myślą przewodnią inicjatywy podjętej w Szkole Podstawowej w Kobylnicy. Szeroko pojmowany folklor, który jest jednym z elementów narodowej świadomości, zawierający zespół dzieł artystycznych, norm, zwyczajów wpajanych od najmłodszych lat członkom społeczności, stał się głównym celem projektu.

Inicjatywa połączyła w sobie treści podstawy programowej muzyki, plastyki, języka polskiego, języka obcego, przyrody, historii, zajęć technicznych, zajęć informatycznych oraz wychowania fizycznego. Przez wzgląd na silne ustrukturyzowanie i szereg zadań w obrębie klas, do opieki nad ich przebiegiem zostali wyznaczeni wychowawcy, natomiast zważywszy na muzyczny charakter głównej części przedsięwzięć, koordynatorem projektu mianowano nauczyciela muzyki.

W prace tą metodą zaangażowane zostały wszystkie oddziały II etapu edukacyjnego - sześć klas. Przez trzy miesiące uczniowie konsultowali swoje zadania z wychowawcami, nauczycielami przedmiotów oraz z koordynatorem projektu.

Nadrzędnym celem projektu, zgodnym z podstawą programową kształcenia ogólnego sześcioletniej szkoły podstawowej, było kształtowanie postawy szacunku wobec polskiego dziedzictwa kulturowego, jego specyfiki regionalnej i odmienności tradycji. Do realizacji tego celu przyczynił się szereg zadań postawionych przed zespołem składającym się ze wszystkich uczniów klasy. Podopieczni mieli do przygotowania prezentację regionu.

Miejscem prezentacji wszystkich elementów, z wyjątkiem śpiewu i tańca, były sale lekcyjne poszczególnych klas, natomiast część muzyczna - śpiew i taniec - odbyła się na sali gimnastycznej przed społecznością szkolną.

\section{Przygotowanie projektu}

Zanim w zagadnienia projektu zostali wprowadzeni uczniowie, podjęto przygotowania związane $\mathrm{z}$ rozplanowaniem logistycznym oraz zakresem merytorycznym materiałów, z których mieli korzystać uczniowie. Szeroki obszar źródłowy związany z głównym tematem projektu narzucił konieczność wyboru sześciu regionów. Kluczem weryfikującym stała się dostępność do wszelkiego rodzaju publikacji oraz promocji zarówno w literaturze, jak i w Internecie. Ważnym czynnikiem był też przeprowadzony wywiad wśród uczniów na temat znajomości kultury regionalnej. Na podstawie zaobserwowanych trendów wybrano sześć regionów: Kaszuby, region kurpiowski, region łowicki, region lubelski, Śląsk oraz Podhale.

Uwzględniając fakt, iż tak duże przedsięwzięcie realizowane metodą projektu było przygotowywane po raz pierwszy, konieczne było odpowiednie przygotowanie uczniów. Zanim przedstawiono główne założenie projektu, 
wychowawcy wraz z koordynatorem uświadamiali uczniom, jak wielkie znaczenie ma samodzielność wykonywanych zadań projektowych, umiejętność pracy w grupie oraz zdolność rozwiązywania ewentualnych konfliktów i szukania kompromisu. Dopiero kolejnym krokiem było wprowadzenie w założenia projektu i wylosowane przez przewodniczącego klasy nazwy regionu przypisanego danemu oddziałowi. Następnie, podopieczni najpierw uczestniczyli $w$ zajęciach na temat folkloru i idei propagowanych przez Oskara Kolberga, aby w dalszej kolejności wraz z koordynatorem nakreślić elementy obligatoryjne wchodzące w skład końcowej prezentacji (forma nie została narzucona), a składało się na nią ukazanie:

- bogactwa stroju regionalnego - męskiego i damskiego;

- kuchni regionalnej - najbardziej charakterystycznych potraw;

- gwary;

- historii regionu i związanych z nim zabytków;

- zwyczajów, obrzędów, legend i mitów;

- terytorium występowania danej kultury;

- fauny i flory regionu;

- charakterystycznych dla regionu wyrobów rzemieślniczych i artystycznych;

- folkloru - utworu wokalnego i tańca.

Wszystkie ustalenia odnośnie tematu, zakresu zadań i podziału obowiązków oraz harmonogramu zostały spisane $\mathrm{w}$ instrukcji przekazanej wychowawcy, którego zadanie polegało na czuwaniu nad jej realizacją. Natomiast, konsekwencje za niewywiązanie się z ustaleń zawartych $\mathrm{w}$ instrukcji zostały przypieczętowane ustnym kontraktem.

Uczniowie zostali poinformowani o możliwości konsultacji z nauczycielami przedmiotów, wychowawcami i koordynatorem projektu podczas zajęć dydaktycznych, zajęć pozalekcyjnych, dyżurów, ale również za pośrednictwem szkolnej poczty elektronicznej. Pełne zaangażowanie zespołów wymagało również spotkań organizowanych we własnym gronie $\mathrm{w}$ domach uczniów, niekiedy nie wykluczając udziału rodziców.

Ostatnim elementem przygotowawczym było wyszukiwanie, gromadzenie i selekcja informacji na temat kultury określonego regionu. Po finalnych konsultacjach sporządzony został wiążący harmonogram. Dbałość o przygotowanie i realizację poszczególnych elementów prezentacji spoczęła na wychowawcach klas. Za przygotowanie piosenki i tańca charakterystycznego dla danego regionu był odpowiedzialny nauczyciel muzyki.

Głównym celem występu artystycznego było wykonanie utworu wokalnego i zaprezentowanie tańca ludowego. Dodatkowy walor stanowiło obudowanie muzycznej prezentacji dowolną formą przedstawienia, do którego scenariusz pisali uczniowie. 
Utwór wokalny i taniec. Pierwszym zadaniem grup składających się z osób, które zgłosiły się do wyszukania muzyki do śpiewu i tańca regionalnego było znalezienie oraz wybranie kilku przykładów muzycznych i skonsultowanie ich z nauczycielem. Główne źródła, z jakich uczniowie mogli korzystać, stanowił Internet oraz szkolna płytoteka. Wybrane przykłady muzyczne, zarówno utwory wokalne, jak i utwory do tańca, musiały spełniać określone wymogi:

- propozycje 2-3 utworów wokalnych i 2-3 utworów do tańca (instrumentalne lub wokalno-instrumentalne) pochodzących $\mathrm{z}$ regionu przypisanego danej klasie;

- każdy przykład utworu wokalnego lub wokalno-instrumentalnego powinien mieć nagranie audio lub audiowizualne;

- utwór do tańca powinien zawierać opis kroków lub nagranie audiowizualne;

- nagrania utworów powinny zachować charakter ludowy (aparat wykonawczy - kapela);

- wybór utworu i nagrania powinien być skonsultowany z nauczycielem muzyki.

Uczniowie bardzo sumiennie i z dużym zaangażowaniem podeszli do swojego zadania, wywiązując się z niego terminowo. Pomimo przeważającej ilości materiału pochodzącego ze źródła internetowego, uczniowie znaleźni również śpiewniki z zapisem nutowym ludowych melodii oraz opisem tańców regionalnych. Po przeprowadzeniu selekcji i konsultacjach, repertuar występów artystycznych przedstawiał się następująco (kolejno: pieśń i taniec):

- klasa IV A - Poszła Karolinka; Zasiali górale;

- klasa IV B - Zaświeć księżycu; Taniec lubelski;

- klasa V A - Łowiczanka jestem; Polonez łowicki;

- klasa V B - Jadą goście, jadą; Żuraw - taniec kurpiowski;

- klasa VI A - Alfabet kaszubski; Szewc;

- klasa VI A - W murowanej piwnicy; Taniec góralski.

\section{Realizacja projektu}

Przygotowania dotyczące dekoracji sal odbywały się głównie $\mathrm{w}$ domach uczniów. Wraz z upływem czasu i zbliżającym się terminem finału projektu, sale lekcyjne nabierały coraz bardziej ludowego charakteru. Uczniowie systematycznie sporządzali gazetki ścienne, przynosili rekwizyty, wymieniali się informacjami i materiałami dotyczącymi regionu oraz konsultowali swoje poczynania z nauczycielami.

Elementy folkloru wpisane zostały w scenariusze spektakli przygotowanych przez uczniów. Młodzi scenarzyści tworząc przestawienie, musieli za- 
angażować aktorsko wszystkich kolegów z klasy. Dzięki powstałym w ten sposób prezentacjom, szkolna publiczność mogła być świadkiem podróży reporterskiej po regionie łowickim, widzem kaszubskiego programu telewizyjnego, uczestnikiem wycieczki po regionie lubelskim oraz obserwatorem pełnego humoru spotkania z podhalańskim bacą. Nie zabrakło również scenariuszy opartych na zwyczajach i obrzędach ukazujących śląski zwyczaj „Wodzenia Niedźwiedzia” oraz obrzęd tradycyjnego kurpiowskiego wesela.

Śpiew w tradycji każdego ludu, ściśle związanego ze swoim regionem, stanowił nieodzowny element obrzędów, zwyczajów, zabawy, a także życia codziennego. Na istotną rangę pieśni ludowych wskazywał Zoltan Kodaly - kompozytor, pedagog, twórca jednego z trzech systemów edukacji muzycznej, który w swych założeniach opierał się na śpiewie melodii ludowych ${ }^{12}$. Ludowe przyśpiewki i pieśni były też jednym z dwóch elementów muzycznych wchodzących w skład prezentacji folkloru regionu, uwzględniając przy tym śpiew jako jedną z podstawowych i fundamentalnych form aktywności muzycznej. Ogromne znaczenie, jakie ma wykonywanie utworów za pomocą głosu, wpływa na wyobraźnię muzyczną, muzykalność oraz stanowi niewątpliwe źródło satysfakcji ${ }^{13}$.

Przygotowania do prezentacji charakterystycznej melodii regionu odbywały się podczas lekcji muzyki. Uczniowie na każdych zajęciach, po uprzednim rozśpiewaniu, z pomocą nut ćwiczyli utwory, dbając o jak najlepsze wykonanie, z zastosowaniem zasad prawidłowego śpiewania i higieny głosu. Warunkiem koniecznym do spełnienia było pamięciowe opanowanie tekstu i melodii utworu.

Wszystkie ćwiczone utwory miały podkład z akompaniamentem kapeli ludowej, z wyjątkiem „Alfabetu kaszubskiego”, który w założeniu uczniów miał być wykonany a cappella. Tekst w języku kaszubskim stanowił dodatkową trudność wykonawczą. Klasa VI, której przyszło zmierzyć się z tą tradycyjną pieśnią kaszubską, organizowała dodatkowe próby w czasie przerw międzylekcyjnych. Pomocą, stanowiącą zarazem nieodzowny element tej wyliczanki, była plansza z rysunkami służąca zabawie, która polegała na tym, że osoba prowadząca zmieniała kolejność wymienianych w piosence przedmiotów ${ }^{14}$.

Każdy region kulturowy ma własne tańce i określone pory, w których organizowano zabawy taneczne, uświęcone tradycją. Okresem szczególnie obfitującym w tego typu zabawy, będącym porą nieustającej radości i we-

12 Z. Kodaly, Pieśń ludowa w wychowaniu muzycznym [w:] Zoltan Kodaly o edukacji muzycznej. Pisma wybrane, red. M. Jankowska, Warszawa 2002, s. 136.

13 M. Przychodzińska-Kaciczak, Polskie koncepcje powszechnego wychowania muzycznego. Tradycje - wspótczesność, Warszawa 1979, s. 169-172.

14 L. Bielawski, A. Mioduchowska, Polska pieśń i muzyka ludowa, t. 2 - Kaszuby. Część III Pieśni powszechne i zawodowe, Warszawa 1998, s. 178-181. 
sela, był czas od Bożego Narodzenia do ostatnich dni karnawału ${ }^{15}$. Taniec jest bardzo namacalną formą doświadczania i przeżywania muzyki. Podczas wykonywania zabaw muzyczno-ruchowych lub układów do utworów, poza kształtowaniem rozwoju ogólnomuzycznego, następuje również rozwój szeregu zdolności poznawczych, takich jak: wyobraźnia, koncentracja, pamięć, postrzeganie i myślenie ${ }^{16}$.

W celu ukazania uczniom wartości kultury tanecznej, do prezentacji włączono element tańca ludowego. Selekcjonując proponowane przykłady taneczne, nauczyciele muzyki i wychowania fizycznego musieli uwzględnić stopień ich trudności. Przechodząc do pierwszych prób tańca, po uprzednim wyborze podkładu muzycznego, mając na uwadze niezbędne wyczucie rytmu wyznaczone zostały osoby, które rozpoczęły naukę kroków.

Podczas prób to właśnie poczucie pulsu stanowiło problem najwyższej wagi. Nieskomplikowane układy taneczne zostały szybko opanowane, jednak ich realizacja okazała się trudna. Problemy rytmiczne pojawiły się w procesie przygotowań każdego spośród sześciu tańców. Konieczne było zintensyfikowanie i wzmożona liczba treningów zarówno pod opieką nauczyciela, jak również indywidualnych ćwiczeń.

Wszyscy uczniowie biorący udział $\mathrm{w}$ prezentacji tańca włożyli wiele pracy w przygotowania. Przykładem takiego wzmożonego wysiłku i zaangażowania nad choreografią może być taniec góralski przygotowywany przez klasę VI. Sześcioosobowy zespół tancerzy spotykał się codziennie po zajęciach na próbach tanecznych, niekiedy podzielonych na dwie sekcje żeńską i męską. Biorąc pod uwagę charakter tańca góralskiego, to panowie odgrywali w tym pokazie najważniejszą rolę, natomiast zadaniem pań było typowe dla podhalańskiego tańca „drobienie”. Rezultat ciężkich treningów był dostrzegalny podczas konsultacji z nauczycielami. Czas intensywnych prób i ogromnego fizycznego wysiłku niósł ze sobą znaczną poprawę, jednakże powszechność problemu związanego z poczuciem rytmu budzi niepokój co do edukacji muzycznej polskiego społeczeństwa.

\section{Publiczna prezentacja rezultatów projektu}

Finałowym dniem zmagań projektowych był 12 lutego 2015 roku. Entuzjazm, jaki uczniowie przejawiali już w początkowej fazie projektu zachęcił dyrekcję szkoły i radę pedagogiczną do organizacji całego dnia poświęconego kulturze ludowej.

Pokaz rozpoczęto od prezentacji udekorowanych sal. Uczniowie podczas wizyty gości przedstawiali walory regionu. Kreatywność i oryginalność połączona z entuzjastycznymi pokazami pozwalała przypuszczać, że uczniowie

\footnotetext{
${ }^{15}$ G. Dąbrowska, Tańcujże dobrze, Warszawa 1991, s. 8.

16 E. Lipska, M. Przychodzińska, Drogi do muzyki, Warszawa 1999, s. 116-117.
} 
utożsamiali się z przedstawianą kulturą. Pomysłów na dekoracje i jej prezentacje było wiele, oprócz wielobarwnych gazetek ściennych i prezentacji multimedialnych zawierających historię, gwarę, zwyczaje, obrzędy, legendy, zakres terytorium oraz walory przyrodnicze, na szczególne wyróżnienie zasługują między innymi: miniatury młyna i chaty kaszubskiej, kurpiowskie wycinanki, makieta pałacu Zamoyskich z Zamościa, zakopiański biały miś, fotościanka kaszubskiego stroju ludowego i wiele innych.

Wszyscy uczniowie $\mathrm{w}$ tym dniu mieli na sobie ludowe stroje regionalne lub ich symboliczne elementy. Na szkolnych korytarzach można było zaobserwować wyczucie prawdziwie regionalnego stylu; pojawiły się białe, często haftowane, koszule, kolorowe spódnice, kwieciste chustki, sznury czerwonych korali oraz przeróżne męskie nakrycia głowy.

Kuchnia regionalna jest ważnym składnikiem dziedzictwa narodowego, a słuszność temu stwierdzeniu nadał również kulinarny akcent. Do degustacji uczniowie przygotowali między innymi: podhalańskie oscypki, lubelskie cebularze, łowickie przetwory oraz kurpiowskie fafernuchy.

Ostatnim elementem prezentacji było przedstawienie efektu dwumiesięcznych przygotowań spektaklu zawierającego pokaz muzycznych zdolności śpiewaczych i tanecznych. Odpowiedzialność i ogromna motywacja do podjęcia wspólnego przedsięwzięcia przyczyniła się do całego procesu tworzenia, realizacji i wykonania wspólnego zamierzenia. Uczniowie sześciu klas II etapu edukacyjnego podczas występów nie tylko obserwowali poczynania rówieśników, ale także mieli okazję w oryginalny sposób poznać inne regiony kulturowe Polski, ich atrakcyjność i specyficzny charakter.

\section{Ewaluacja projektu}

Dopełnieniem metody projektu jest ewaluacja. Podczas wszystkich faz prace nad realizacją były systematycznie monitorowane przez nauczycieli. Istotne było również określenie jakości i efektów pracy ucznia. Obraną techniką badawczą, która miała pozyskać pożądane informacje, była ankieta.

Dzień po zakończeniu projektu każda klasa spotkała się z koordynatorem projektu, w celu analizy osiągniętych sukcesów i popełnionych w czasie przygotowań błędów. Narzędziem dopełniającym ewaluację był anonimowo wypełniony przez uczniów kwestionariusz ankiety. Odpowiednio przygotowany, zawierał dziesięć pytań, z czego trzy były typu otwartego, a siedem - zamkniętego. W badaniach wzięło udział 84 uczniów ze wszystkich sześciu oddziałów.

Pierwsze pytanie dotyczyło zrozumienia powierzonych zadań. Ocena stopnia percepcji zagadnień związanych z przygotowaniem uczniów do projektu w opinii ankietowanych była pozytywna. 72 osoby wskazały na odpowiedź "tak”, natomiast 12 wybrało odpowiedź „raczej tak”. Nikt spośród ankietowanych nie zaznaczył odpowiedzi „raczej nie” i „nie”. 
Kolejne pytanie dotyczyło atrakcyjności tematu projektu. W ogólnym zestawieniu uczniom odpowiadała tematyka, 60 osób odpowiedziało ",tak”, a 11 - "raczej tak". Natomiast 9 respondentow odpowiedziało "nie” i 4 - „raczej nie”.

Zadania, którym uczniowie mieli sprostać, okazały się atrakcyjne, większość (76 osób) określiła je jako ciekawe, natomiast 7 osób oceniło je jako przeciętne. Jednemu uczniowi zadanie nie przypadło do gustu.

W czwartym zadanym pytaniu uczniowie wskazali na dobrą współpracę w obrębie klasy - 70 osób zaznaczyło, że współpraca układała się „dobrze”, 14 - „raczej dobrze”. Nikt spośród ankietowanych nie wskazał odpowiedzi "źle”, co mogło również wpłynąć na pozytywny wydźwięk kolejnego pytania, które dotyczyło oceny zaangażowania w działania projektowe całej grupy. 59 uczniów wskazało na pełne zaangażowanie całej klasy, 22 określiło, że w pracach uczestniczyli "prawie wszyscy”, natomiast tylko 3 osoby stwierdziły, że chętna do pracy była tylko połowa klasy. Być może zaangażowanie uczniów w występ artystyczny pozwala na przypuszczenie, iż odpowiedzi „mniejszość” i „niewielka grupa” nie zostały przez uczniów wybrane.

W szóstym pytaniu typu otwartego 65 respondentów napisało, że powierzone zadania nie sprawiły im problemu, 4 osoby pozostawiły puste miejsce na odpowiedź, natomiast problemy, jakie uczniowie sformułowali, dotyczyły znalezienia informacji na temat regionu (nie wszystkie informacje można było znaleźć w Internecie), śpiew w języku kaszubskim, trudności w nauczeniu się gwary (brak dostępu do źródeł), jednak najwięcej wypowiedzi pojawiło się w stosunku do nauki tańca (12 osób).

Odpowiadając na kolejne pytanie, uczniowie przyznali, że korzystali przede wszystkim z pomocy rodziców (66 osób) i nauczycieli (70 osób). Grono doradcze stanowili również inni członkowie rodziny oraz rówieśnicy.

W pytaniu ósmym: „Czego nauczyłeś/nauczyłaś się przy okazji realizacji projektu?" uczniowie najczęściej wskazywali na poznanie bogactwa folkloru (melodii, utworów i tańców ludowych), tradycji, zwyczajów, historii, gwary, strojów ludowych, obszaru i położenia regionów. Pojawiały się również odpowiedzi związane z tworzeniem scenariusza, nauką tańca, budową młyna, rysowaniem mapy, nauką języka kaszubskiego, kształtowaniem zdolności kulinarnych oraz możliwością degustacji potraw regionalnych. Odpowiedzi na to pytanie zapewne były zależne od tego, jakie zadanie było przydzielone określonemu respondentowi.

Zdaniem większości ankietowanych, proponowana forma zdobywania wiedzy i umiejętności jest odpowiednia. Spośród trzech możliwych odpowiedzi za wyborem "tak" opowiedziały się aż 82 osoby, tylko 2 określiły, że "trudno powiedzieć”. Satysfakcjonujący jest fakt, że metoda uzyskała tak pozytywny wydźwięk wśród społeczności szkoły. Tak dobra opinia pozwala 
przypuszczać, iż w takiej formie kształcenia uczniowie bardzo chętnie mogliby uczestniczyć w przyszłości. Przypuszenie to ma odzwierciedlenie w ostatnim pytaniu zawartym w kwestionariuszu. Aż 83 osoby (72 odpowiedzi ",tak” i 11 „raczej tak") chętnie wzięłyby ponowny udział w podobnym projekcie. Tylko jedna osoba wskazała "raczej nie”.

\section{Podsumowanie projektu}

Zrealizowany projekt „Muzyczna Kawaleriada z Uśmiechem - Regiony kulturowe Polski" przygotowany został z myślą o uczniach II etapu edukacyjnego, którzy wykazali nim duże zainteresowanie oraz aktywnie uczestniczyli w realizacji wyznaczonych celów.

Wzajemne wsparcie i zdyscyplinowanie doprowadziło do terminowego ukończenia powierzonych zadań i osiągnięcia zamierzonych celów. Również praca indywidualna miała istotne znaczenie $\mathrm{w}$ przygotowaniach oraz podczas realizacji projektu, a widoczne to było szczególnie podczas konsultacji i spotkań monitorujących działania grup, które proponowały wiele autorskich rozwiązań.

Udział w projekcie umożliwił uczniom pracę $\mathrm{w}$ grupie, docieranie do rożnych źródeł informacji, formułowanie i wyrażanie własnych myśli, okazał się również sposobem na realizację swoich pomysłów. Aktywne uczestnictwo $\mathrm{w}$ nim przyniosło uczniom korzyść $\mathrm{w}$ postaci poszerzenia wiedzy na temat kultury polskiej, a ponad to wpłynęło na doskonalenie takich cech, jak: aktywność, pomysłowość, umiejętność współpracy oraz wzbudziło poczucie wiary we własne możliwości.

Przeprowadzony w Szkole Podstawowej w Kobylnicy projekt ukazuje, że tego typu inicjatywy mają szansę powodzenia. Przede wszystkim z takiego powodu, iż takie działania mogą stanowić ciekawe doświadczenie zarówno dla prowadzących go nauczycieli, jak też uczestniczących w nim grupach uczniowskich. To duże wyzwanie dla ambitnych i kreatywnych uczestników, co może przemawiać za tym, iż uczniowie z ochotą przystąpią do kolejnych projektów.

Powodzenie projektu dowiodło, że stał się on przedsięwzięciem, które umożliwiło kształtowanie umiejętności muzycznych z dodatkową, wydawać by się mogło, barierą, jaką przypuszczalnie mógłby stać się folklor. Dzięki tego typu przedsięwzięciom uczniowie przełamując barierę nieśmiałości, mają okazję kształtować umiejętność wyrażania opinii, słuchania innych, podejmowania decyzji grupowych oraz samooceny wykonanej pracy. Zaplanowane $\mathrm{w}$ tym przedsięwzięciu działania miały za zadanie przybliżyć dzieciom pojęcie folkloru, jego znaczenie i wartość, a przede wszystkim aktywnie przeżywać muzykę poprzez śpiew i taniec. Podsumowując projekt, można stwierdzić, że wszystkie założenia udało się osiągnąć. 


\section{BIBLIOGRAFIA}

Bielawski L., Mioduchowska A., Polska pieśń i muzyka ludowa, t. 2 - Kaszuby. Część III - Pieśni powszechne i zawodowe, Warszawa 1998.

Dąbrowska G., Tańcujże dobrze, Warszawa 1991.

Dylak S., Barabasz G., Hejwosz-Gromkowska D., Metoda projektów w edukacji ponadpodstawowej (na przykładzie przedmiotów przyrodniczych), Poznań 2014.

Gołębniak B.D., Uczenie metodą projektów, Warszawa 2002.

http://www.kolberg2014.org.pl/pl/2014/idea

Kilpatrick W.H., The Project Method, Teachers College Record, 1918, XIX, 4.

Kodaly Z., Pieśń ludowa w wychowaniu muzycznym, [w:] Zoltan Kodaly o edukacji muzycznej. Pisma wybrane, red. M. Jankowska, Warszawa 2002.

Krajcik J.S., Blumenfeld P.C., Project - based learning, [w:] Cambridge handbook of learning sciences, red. K. Sawyer, Cambridge 2006.

Lipska E., Przychodzińska M., Drogi do muzyki, Warszawa 1999.

Mikina A., Zając B., Metoda projektów w gimnazjum, Warszawa 2002.

Mikina A., Zając B., Jak wdrażać metodę projektów? Poradnik dla nauczycieli i uczniów gimnazjum, liceum i szkoły zawodowej, Kraków 2004.

Potocka B., Nowak L., Projekty edukacyjne, Kielce 2002.

Przychodzińska-Kaciczak M., Polskie koncepcje powszechnego wychowania muzycznego. Tradycje - wspótczesność, Warszawa 1979.

Szymański M.S., Wokót metody projektów Karla Freya, Kwartalnik Pedagogiczny, 1993, 3/4.

Szymański M.S., Rozprawa o metodzie (projektów), [w:] Pedagogika w pokoju nauczycielskim, red. K. Kruszewski, Warszawa 2000. 